\title{
Halal Tourism through the Lens of Generation Z in a Muslim Majority Country: Implications on Tourist Services
}

\author{
Alfonso Vargas-Sanchéz ${ }^{1} \&$ Mirko Perano $^{2}$ \\ ${ }^{1}$ Management and Marketing Department, University of Huelva, Huelva, Spain \\ ${ }^{2}$ Department of Management, Reald University College, Vlore, Albania \\ Correspondence: Mirko Perano, Department of Management, Reald University College, Vlore, Albania. E-mail: \\ mperano@unisa.it
}

Received: June 8, 2018

doi:10.5539/ijbm.v13n9p36

\author{
Accepted: July 18, 2018 \\ Online Published: August 1, 2018 \\ URL: https://doi.org/10.5539/ijbm.v13n9p36
}

\begin{abstract}
The aim of this paper is twofold: to contribute to clarifying what exactly Halal tourism is, being a relatively new term; and to provide an insight into the level of knowledge and mental schemes of a new generation (Gen Z) in a Muslim majority country. To achieve the first aim, a literature review is presented. With regard to the second, a survey among Business School university students was carried out in Indonesia; primary data collected were treated by using univariate, bivariate and multivariate statistical techniques. The main findings obtained show that (1) scientific research on Halal tourism is still in an early stage, with the first relevant article dated in 2010; and (2) only a minority of our target population has declared to be familiar with the concept of Halal tourism and to have received specific training on it, but most of them (males particularly) believe that Indonesia should bet decisively to position itself as a Halal tourism destination, being its religious profile the most influential factor in favor of that option. This is the first work on this topic targeting university students' perceptions. Implications on the supply of services in the tourism industry are also provided.
\end{abstract}

Keywords: Halal tourism, Halal destination, new generation's perceptions, Indonesia, tourist services

\section{Introduction}

Investigating on the Halal tourism as a niche of the tourism market, the first problem a researcher faces is the confusion provoked by a series of terms intended to designate the same concept (Islamic tourism, Sharia-compliant tourism, Halal tourism, etc.). In addition to the lack of a single accepted term, it is not clear what Islam requirements consist in with regard to tourism services. As stated by Maznui (1997), "Islam is not just a religion and certainly not just a fundamentalist political movement. It is a culture or civilization, a way of life that varies from one Muslim country to another but it is spirited by a common core" (p. 118).

The Halal tourism is a fast-growing market segment but at the same time is still very under researched. "In 2017, there were an estimated 131 million Muslim visitor arrivals globally - up from 121 million in 2016 - and this is forecasted to grow to 156 million visitors by 2020 representing 10 percent of the travel segment" (GMTI, 2018, p. 3). The travel expenditures of Muslim tourism segment for 2026 have been globally estimated in 300 billion of US\$ (ibidem) in which are included also the hospitality services. Therefore, this is an opportunity for hoteliers and other tourism operators to increase their competitiveness through the configuration of specific services designed for Muslim travellers, matching their quality standards.

Bearing this in mind, this work divided into two main parts, reflecting its dual aim: a synthesis is presented of the state of the art on scientific research on Halal tourism seemingly the most appropriate term and which in recent times has gained momentum among the experts. The other, of an empirical nature, which aims to provide an insight into the level of knowledge and mental schemes of the new generation of university students in Muslim majority countries such as Indonesia, based on a survey carried out among business students in a higher education institution (President University). Considering the GMTI (Global Muslim Travel Index) 2018, Indonesia is the second best geared country to attract the Muslim travel market (only behind Malaysia).

The relevance of the new generation born in the mid-1990s, usually termed as Gen Z, is that there are around 2 billion Gen Zers worldwide, Indonesia being one of the countries with the highest percentage of its population in this demographic cohort (Sinhg, 2013). Therefore, a deep understanding of their expectations, and the 
corresponding effort to match them, is an essential remit for Halal tourism firms and for its future growth. In this respect, a number of practical implications are to be gathered as a result of this study. It should be noted that in Islam the concept of Halal is intended, among other meanings, "to protect future generations" (Jaelani, 2017).

\section{Theoretical Framework}

In order to build a theoretical framework, a literature review was compiled. According to Fink (1998), this "is a systematic, explicit, and reproducible design for identifying, evaluating, and interpreting the existing body of recorded documents". Usually, a literature review summarizes the existing research by identifying patterns, themes and issues, as well as helps to identify the conceptual content of the field under study (Meredith, 1993) and contributes to theory development.

In this case, two subsections will be presented. The first synthesizes the state of the art in the field of Halal tourism. The second by means of relevant notes informs and enlightens on the so-called generation Z .

\subsection{Halal Tourism}

The first evidence that "Halal tourism" is a relatively new and under-researched topic is the very limited number of outputs supplied by Web of Science when searched in its scientific database: only 13 (including one editorial) has been published during the last three years (2014-2016), 10 of them in 2016. The vast majority (9) have been published in the journal "Tourism Management Perspectives", 7 of them in a special volume (19 part B).

No researcher (nor institution) holds an outstanding position in terms of number of papers authored, although the most represented country of origin is Malaysia (4 authors). Only one paper has been written in a language other than English (Korean). The number of times these papers have been cited is very limited, with none of them standing out significantly.

If research on "Halal tourism" is complemented with Scopus (in title, abstract and keywords), its database adds some more documents in its list of 18 supplied results, 15 articles and 3 book chapters (all of them in the English language).

The first article published on the topic was in 2010, co-authored by Battour, Ismail \& Battor, who seem to be pioneers. In addition, the work is the most cited. Once again, this fact demonstrates the immaturity of the research strand labelled "Halal tourism". Nevertheless, others labels (such "Islamic tourism") have been used as synonymous, quite inaccurately. As a matter of fact, the breakdown of keywords is headed by "Halal tourism" (13), followed by "Islamic tourism" (6). Authors from Malaysia are found as the most frequent.

A total of 22 papers were found adding the results of both databases (21 during the period 2010-2016). More than half (12) were published in 2016. Others were issued in 2015 (2), 2014 (4), 2011 (2) and 2010 (1).

The observation of the keywords used points out the prevalence of conceptual aspects within the "umbrella" of Halal tourism (often referred to as Islamic tourism - Note 1), such as Halal food, Halal hospitality/lodging or Halal products in general. The references to the religious/cultural framework of this type of tourism are ubiquitous, with frequent allusions to Islam and compliance with Shariah principles. The accommodation sector has caught the attention of a significant number of papers with Asian (Malaysia, Singapore) and African (Morocco, Tunisia, South Africa) countries the most common geographical focus. Nevertheless, New Zealand and the Czech Republic have been analysed from a supply perspective (the latter specifically with regard to Russian tourists) and the USA from a demand perspective (Muslim travelers' behavior in that country). Russia and South Korea have been tackled from the point of view of the development/promotion of Halal tourism in these countries, and India in the particular case of Halal medical tourism. Finally, these outputs are not particularly robust or distinctive because of their theoretical and methodological backgrounds; just the use of Coordinated Management of Meaning Theory and Content Analysis methodology would deserve a mention.

To sum up, as a field of study under construction, fundamentally this set of papers can be divided in two clusters, based on their main objectives:

- The conceptual definition of the phenomenon under study, attempting to contribute to the creation of a common understanding, terminology, scope and boundaries.

- The provision of a specific insight on the situation of this topic in certain countries, particular experiences or particular types of tourists from a marketing angle.

\subsection{Generation $Z$}

In this subsection we present profiles of this generation selected by virtue of their link to our field of study and, therefore, able to help in the interpretation of our results. For this reason, our search has been narrowed to its 
specific features in the geographical area of our research and to those attributes with a potential to shed some light on the understanding of the travel-and-tourism phenomenon by this new generation in a Muslim majority country.

Born after the mid-1990s, it can be considered the first truly digital native generation and the first real generation of global citizens with global aspirations, in which online connectivity has permeated their lives and transformed how they interact. More specifically related to our research, we are facing a new cohort of Muslims described as "vigorous and adventurous" (Verghese, 2017), with a more accentuated entrepreneurial spirit and boundless curiosity (Ghosh, 2016). As the first generation born into a fully technological environment, that has never known life without easy Internet access and mobile technology, they are more prepared for searching information and figuring things out on their own; this has made them "more self-aware, self-reliant and driven" (Hays, 2017).

Being born from Generation X parents (people born between 1960s-1970s), Generation Z is mostly influenced by Generation Y or Millennials (people born between 1980s to mid-1990s). Thus, similar to Generation Y, Generation $\mathrm{Z}$ is also familiar with advanced technology, "but they have higher awareness concerning privacy", guided by their critical thinking about politics and humanity: "They want the things they do to have impacts on the world" (Pudjiarti, 2015; Half, 2016). This leads to the need to provide a sense of purpose for them: "This generation wants to understand why an organisation does what it does and how their role contributes to its success. They want a clear purpose" (Hays, 2017). In other words, they can be characterized as cause-and-value driven people, although realistic at the same time, yet they have grown up in a time of severe economic and geopolitical turmoil.

In the GMTI 2017, "two key megatrends were identified as driving Muslim-friendly travel: the millennial and Generation Z demographic, and technology that will increase access to travel information" (Abdul Alim, 2017). Based on this report (GMTI 2017), this (post-Millennials) group is extremely connected with each other and the environment around them. As the Internet and social environments play key roles in their everyday lives, "the Muslim travel industry must evolve their offerings to ensure that their brands are reintroduced to these new segments and that their Muslim-friendly services are Authentic, Affordable and Accessible to these young segments" (p. 7).

Research by HalalTrip, an online travel platform, suggests that Gen Z (together with Gen Y) represents an important youth travel segment in the Muslim Travel Market. The global Muslim population is projected to rapidly grow largely because of its standing as the youngest population of all major religious groups, with an average age of 23,7 years younger than the global average (Lipka, 2016). As it is, global youth travel constitutes $25 \%$ of the annual travel visitor arrivals with the figure amounting to 1.1 billion (UNWTO \& WYSE Travel Confederation, 2016).

With reference to Indonesia, and according to Fazal Bahardeen, CrescentRating \& HalalTrip CEO: "We are definitely seeing the influence of a new breed of young travelers, millennials and generation $\mathrm{Z}$ who are combining technology with real desire to explore the world, while still adhering to their faith-based needs" (Bahardeen, 2017).

A very comprehensive view about this generation is provided by Broadbent et al (2017). Some of the key statistics about Indonesian Gen Z follow:

- Indonesian young people are the happiest in the survey by a substantial margin - scoring $90 \%$ on the net happiness score.

- Indonesia had the highest proportion of young people who have good emotional wellbeing $(40 \%)$ - who do not think about problems too much and do not typically feel anxious, bullied, unloved or lonely.

- Young people in Indonesia are the most likely of any country to state that religious faith is important to their happiness (93\%). Nevertheless, being healthy -both physically and mentally- is the most important factor contributing to overall happiness ( $97 \%$ said this factor is important or very important).

- The proportion of young people who have good relationships (who feel they have a good relationship with their parents and a strong relationship with friends) is the largest among the 20 countries in this report (81\%).

A final note about the influence of religion: religious faith can be said to be highly important to $27 \%$ of Indonesian Gen Zers (Note 2), the second largest proportion in this study.

\section{Empirical Work: Methodology}

\subsection{Population and Sample}


Our target population was composed of the undergraduate students enrolled in the Business School of President University (Indonesia) during the 2016-2017 academic year. In this regard, two relevant annotations should be taken into account:

- Indonesia is a Muslim-majority country, with the single largest population of Muslims in the world, which on its own hosts around 13\% of the world's Muslims (Pew Research Center, 2011).

- President University is a 100\% English-speaking higher education institution in Indonesia, which has facilitated the primary data collection in that language.

441 questionnaires (practically the whole target population) were collected during March 2017, from which 168 declared a level of familiarity with Halal tourism of at least 5 (out of 7). This set was taken as our sample ( $38 \%$ of total).

The lack of familiarity, declared by most of these youngsters in Indonesia, cannot be considered as exceptional. For instance, in Malaysia, a neighboring country with cultural similarities, Selvarajah et al. (2017) a broad lack of awareness was also found among members of generation $\mathrm{Z}$ towards Halal food, and in general the Halal concept. It has to be noted that the cohort of age of the elements in our population and sample belongs to the post-millennials generation, also known as generation $\mathrm{Z}$.

\subsection{Population and Sample}

The questionnaire was structured in six sections:

1. The first investigates the level of familiarity with the concept of Halal tourism. This is important because only the answers coming from informants who have been rated by themselves with a level of at least 5 (out of 7) have been considered.

2. The second informs on whether some specific training (course, seminar, workshop or similar) has been attended by the respondents.

3. The third asks for a personal definition of Halal tourism.

4. The fourth ascertains the informant's opinions on whether Indonesia should bet decisively to position itself as a Halal tourism destination.

5. Section 5 is the most complex, with eighteen items. Their corresponding theoretical foundations are summarized in table 1 .

Table 1. Theoretical foundations of items in the questionnaire

\begin{tabular}{|c|c|}
\hline Items & Theoretical Foundations \\
\hline 5.01.-Spiritual dimension. & $\begin{array}{l}\text { Battour et al. (2010); Carboni \& Janati (2016); El-Gohary (2016); Jafari \& Scott (2014); Oktadiana et al. } \\
\text { (2016); Samori et al. (2016); Zamani-Farahani and Henderson (2010). }\end{array}$ \\
\hline 5.02.-Ecological dimension. & Jafari \& Scott (2014); Stephenson (2014); Oktadiana et al. (2016). \\
\hline 5.03.-Health dimension. & $\begin{array}{l}\text { Henderson (2010); Jafari \& Scott (2014); Stephenson (2014); Oktadiana et al. (2016); Zamani-Farahani \& } \\
\text { Henderson (2010). }\end{array}$ \\
\hline 5.04.-Size and growth. & $\begin{array}{l}\text { Battour et al. (2011); Carboni \& Janati (2016); El-Gohary (2016); Hamza et al. (2012); Henderson (2010); } \\
\text { Jafari \& Scott (2014); Mohsin et al. (2016); Samori et al. (2016); Stephenson (2014); Oktadiana et al. } \\
\text { (2016); WTM (2007); Zamani-Farahani \& Henderson (2010). }\end{array}$ \\
\hline 5.05.-Level of expenditure. & Battour \& Ismail (2016); El-Gohary (2016); Stephenson (2014); WTM (2007). \\
\hline $\begin{array}{l}\text { 5.06.-Religious and cultural } \\
\text { similarities. }\end{array}$ & $\begin{array}{l}\text { Henderson (2010); Oktadiana et al. (2016); Sandikci (2011); Stephenson (2014); Zamani-Farahani \& } \\
\text { Henderson (2010). }\end{array}$ \\
\hline $\begin{array}{l}\text { 5.07.-Diversity of origins and } \\
\text { needs. }\end{array}$ & $\begin{array}{l}\text { Henderson (2010); Jafari \& Scott (2014); Mukhtar \& Butt (2012); Sandikci (2011); Stephenson (2014); } \\
\text { Zamani-Farahani \& Henderson (2010); Zamani-Farahani \& Musa (2012). }\end{array}$ \\
\hline $\begin{array}{l}\text { 5.08.-Adaptations of the offer } \\
\text { and certifications. }\end{array}$ & $\begin{array}{l}\text { Battour et al. (2010); Battour \& Ismail (2016); El-Gohary (2016); Henderson (2010); Henderson (2016); } \\
\text { Moshin et al. (2016); Oktadiana et al. (2016). }\end{array}$ \\
\hline 5.09.-Level of knowledge. & $\begin{array}{l}\text { Battour et al. (2011); Battour \& Ismail (2016); El-Gohary (2016); Henderson (2010); Henderson (2016); } \\
\text { Jafari \& Scott (2014); Razzaq et al. (2016); Stephenson (2014). }\end{array}$ \\
\hline $\begin{array}{l}\text { 5.10.-Suitability of the } \\
\text { experience for any type of } \\
\text { public. }\end{array}$ & Jafari \& Scott (2014); Stephenson (2014), \\
\hline 5.11.-Muslims as target & Henderson (2010); Scott \& Jafari (2010). \\
\hline
\end{tabular}


population.

5.12.-Religious motivations.

5.13.-Particular food and

catering services.

5.14.-Welcoming character of

the resident population.

5.15.-Seasonality mitigation.

5.16.-Impact of the global

geopolitical situation.

5.17.-Capacity of integration in

the host community.

5.18.-Potential for promoting

mutual understanding.
Battour et al. (2011); El-Gohary (2016); Jafari \& Scott (2014)

Battour et al. (2011); Battour \& Ismail (2016); Carboni \& Janati (2016); El-Gohary (2016); Henderson (2010); Razzaq et al. (2016); Stephenson (2014).

Carboni et al. (2014); Jafari \& Scott (2014); Shakona et al. (2015); Stephenson (2014); Oktadiana et al. (2016).

Stephenson (2014); Zamani-Farahani \& Henderson (2010).

Battour \& Ismail (2016); Jafari \& Scott (2014); Stephenson (2014); Oktadiana et al. (2016); Zamani-Farahani \& Henderson (2010).

Carboni et al. (2014); Carboni \& Janati (2016); Hamza et al. (2012); Jafari \& Scott (2014); Oktadiana et al. (2016); Zamani-Farahani \& Henderson (2010).

Battour et al. (2010); Carboni \& Janati (2016); Stephenson (2014); Moshin et al. (2016); Oktadiana et al. (2016).

The three first items reflect Halal tourism as a three-dimensional construct, formed of spiritual, ecological and healthy dimensions, respectively.

The remaining fifteen are intended to sketch its profile, with a number of factors that can be organized in three theoretical blocks:

- Factors of economic character, influencing its level of attractiveness directly: size and growth; level of expenditure; adaptations of the offer and certifications; level of knowledge; seasonality mitigation; impact of the global geopolitical situation.

- Factors of social character derived from its religious background: religious and cultural peculiarities; diversity of origins and needs; Muslims as target population; religious motivations; food and catering services.

- Factors of social character that can promote cultural integration to some extent: suitability of the experience for any type of public; welcoming character of the resident population; capacity of integration in the host community; potential for promoting mutual understanding.

The last section describes the socio-demographic profile of the sample, with three items (gender, age and nationality), which can also be useful (particularly gender and nationality, due to the homogeneity in age) to identifying potential significant statistical differences in the responses collected.

\subsection{Techniques Applied}

Univariate, bivariate and multivariate techniques were applied for data processing, as detailed in the next section.

SPSS 20.0 was used.

\section{Results}

\subsection{Univariate Analysis: Descriptive Statistics}

They have been calculated on the abovementioned 168 observations.

Table 2 (divided in two parts, $2 a$ and $2 b$ ) summarizes the descriptive statistics of variables in the questionnaire.

Table 2a. Descriptive statistics (sections 1, 2, 4 and 6 of the questionnaire)

\begin{tabular}{ll}
\hline Variable & Values \\
\hline Gender & $59.5 \%$ female; $40.5 \%$ male \\
Nationality & $85.7 \%$ Indonesian; $14.3 \%$ foreigners $(11.8 \%$ Chinese) \\
Age (years) & Mode $20 ;$ Median $21 ;$ Mean 20.8, Standard Deviation 1.2 (within the age span \\
Specific training on Halal tourism & of generation Z) \\
Indonesia as a Halal destination & $29.3 \%$ yes; $70.7 \%$ no \\
\hline
\end{tabular}


Table 2b. Descriptive statistics (section 5 of the questionnaire)

\begin{tabular}{|c|c|c|c|}
\hline Item & Median & Mode & $\begin{array}{c}\text { Mean } \\
\text { (St. Dev.) }\end{array}$ \\
\hline 5.01.-Spiritual dimension. & 5 & 5 & $4.61(1.94)$ \\
\hline 5.02.-Ecological dimension. & 5 & 6 & $4.71(1.84)$ \\
\hline 5.03.-Healthy dimension. & 6 & 6 & $5.44(1.65)$ \\
\hline 5.04.-Size and growth. & 5 & 6 & $4.68(2.08)$ \\
\hline 5.05.-Level of expenditure. & 5 & 6 & $4.53(1.94)$ \\
\hline 5.06.-Religious and cultural similarities. & 5 & 5 & $4.73(1.82)$ \\
\hline 5.07.-Diversity of origins and needs. & 5 & 6 & $4.74(1.73)$ \\
\hline 5.08.-Adaptations of the offer and certifications. & 5 & 6 & $5.13(1.65)$ \\
\hline 5.09.-Level of knowledge. & 5 & 6 & $4.71(1.88)$ \\
\hline 5.10.-Suitabulity of the experience for any type of public. & 5 & 6 & $4.97(1.68)$ \\
\hline 5.11.-Muslims as target population. & 6 & 7 & $5.21(1.79)$ \\
\hline 5.12.-Religious motivations. & 6 & 7 & $5.51(1.64)$ \\
\hline 5.13.-Particular food and catering services. & 5 & 7 & $5.10(1.76)$ \\
\hline 5.14.-Welcoming character of the resident population. & 6 & 6 & $5.26(1.74)$ \\
\hline 5.15.-Seasonality mitigation. & 5 & 6 & $4.65(1.96)$ \\
\hline 5.16.-Impact of the global geopolitical situation. & 5 & 6 & $4.90(1.87)$ \\
\hline 5.17.-Capacity of integration in the host community. & 5 & 5 & $4.79(1.73)$ \\
\hline 5.18.-Potential for promoting mutual understanding. & 6 & 6 & $5.46(1.55)$ \\
\hline
\end{tabular}

\subsection{Bivariate Analysis: Statistically Significant Differences}

About having received specific training on Halal tourism, its lack is significantly more acute in the group of female students, in total and among Indonesians, according to the corresponding contingency tables and Chi-square tests.

Concerning the question on whether Indonesia should bet decisively to position itself as a Halal tourism destination, the response is influenced by respondent's nationality and gender. After the application of the Chi-square test, the findings were:

- Indonesians are mostly inclined to answer positively, while majority indecision is among foreigners.

- With regard to gender, although in both groups the majority is inclined to answer positively, a more noticeable indecision is found among females. The same result is obtained when the gender test is done for Indonesians only.

The Mann-Whitney $U$ test was administered to the 18 items in section 5 , in relation to the socio-demographic variables nationality (Indonesian and others) and gender. The results follow:

- The following items show statistically significant differences according to nationality (Indonesians are more inclined to highlight the corresponding attributes): spiritual dimension; health dimension; level of expenditure; religious and cultural similarities; diversity of origins and needs; Muslims as target population; religious motivations; welcoming character of the resident population; seasonality mitigation.

- The following items show statistically significant differences according to gender (females value them higher than males): health dimension; level of expenditure; religious and cultural similarities; diversity of origins and needs; adaptations of the offer and certifications; Muslims as target population; religious motivations; particular food and catering services. Nevertheless, males (also for Indonesians only) value higher than females the size and growth expectations of this market segment.

\subsection{Multivariate Analysis: Factor and Cluster Analysis}

An exploratory factor analysis was carried out on the data matrix composed of the 15 items in section 5 to draw the profile of this market segment (5.04 to 5.18), once checked its suitability with tests such as: correlation matrix determinant, Bartlett's test of sphericity and the KMO (Kaiser-Mayer-Olkin) index. Their outputs follow:

- Correlation matrix determinant $=0.011$.

- Bartlett's test of sphericity Sig 0,000 Approx.

- $\mathrm{KMO}$ index $=0.747$. 
As a dimensions reduction technique, a Principal Component Analysis was performed, using the Kaiser method for component extraction and Varimax method for their rotation. The rotated components matrix obtained as a result (with a proportion of variance explained of $59 \%$ ) is displayed in table 3.

Table 3. Rotated components matrix

\begin{tabular}{|c|c|c|c|c|}
\hline \multirow{2}{*}{ Item } & \multicolumn{4}{|c|}{ Components } \\
\hline & F1 & $\mathrm{F} 2$ & F3 & F4 \\
\hline 5.04.-Size and growth. & -0.037 & -0.034 & -0.024 & 0.670 \\
\hline 5.05.-Level of expenditure. & 0.262 & 0.761 & 0.106 & 0.080 \\
\hline 5.06.-Religious and cultural similarities. & -0.040 & 0.749 & 0.358 & 0.050 \\
\hline 5.07.-Diversity of origins and needs. & -0.250 & 0.399 & 0.650 & -0.058 \\
\hline 5.08.-Adaptations of the offer and certifications. & 0.443 & 0.565 & -0.087 & 0.071 \\
\hline 5.09.-Level of knowledge. & 0.483 & 0.499 & 0.019 & 0.012 \\
\hline 5.10.-Suitabulity of the experience for any type of public. & 0.114 & 0.357 & -0.041 & 0.679 \\
\hline 5.11.-Muslims as target population. & 0.211 & 0.035 & 0.810 & -0.027 \\
\hline 5.12.-Religious motivations. & 0.028 & 0.075 & 0.701 & 0.103 \\
\hline 5.13.-Particular food and catering services. & 0.416 & -0.039 & 0.655 & 0.141 \\
\hline 5.14.-Welcoming character of the resident population. & 0.590 & 0.531 & -0.032 & 0.021 \\
\hline 5.15.-Seasonality mitigation. & 0.793 & 0.201 & 0.217 & 0.009 \\
\hline 5.16.-Impact of the global geopolitical situation. & 0.749 & 0.132 & 0.140 & -0.200 \\
\hline 5.17.-Capacity of integration in the host community. & 0.535 & 0.042 & 0.028 & 0.317 \\
\hline 5.18.-Potential for promoting mutual understanding. & 0.001 & -0.026 & 0.192 & 0.681 \\
\hline
\end{tabular}

According to this output, the collective mental scheme about Halal tourism for this batch of higher education students can be built around four factors, which we have termed: "The role of locals and seasonal benefit" (F1); "Expenditure and similarities" (F2); "Religious profile" (F3); "Cultural integration and size-and-growth attractiveness" (F4).

This exploratory factor analysis was complemented by a confirmatory factor analysis, reaffirming our results. The later was performed using WarpPLS 6.0.

The rationale has been associated with various clusters of informants. To do so, a hierarchical cluster analysis has been also completed, using the Ward method and the squared Euclidean distance. As a result, and based on the dendrogram, four clusters were identified, with the following characteristics:

- The most numerous one by far is integrated by 102 observations (61\%), mainly inclined to favour factors related to cultural integration and economic impact ( 1 and 4 in our analysis). The position of Indonesia as a Halal tourism destination is defended by the majority (two-thirds) of informants in this cluster (very mostly Indonesians and particularly among them), being very few those who are against it.

- Next cluster has 30 cases (18\%), being characterized by favouring the economic attractiveness of this segment and its social closeness to a country such as Indonesia (factor 2), without particularly emphasizing its religious profile (factor 3). Its position as a Halal tourism destination is not supported by the majority of its members (particularly among Indonesians).

- The third by quantity of cases has $27(16 \%)$, its main trait being its relative estrangement from our factor 4 (cultural integration and attractiveness because of its size and growth). The result is the lack of definition of most of them (two-thirds) on whether Indonesia should position itself as a Halal tourism destination (particularly among Indonesians).

- Finally, the smallest cluster (with 9 observations only, 5\%) favours clearly the religious profile of this market segment (factor 3 ). Within this cluster (100\% of Indonesian nationality), there are no negative responses to the question on whether Indonesia should bet to position itself as a Halal tourism destination.

As a final methodological step, a discriminant analysis was executed in order to confirm this clustering, resulting that $92.3 \%$ of the original clustered cases were correctly classified.

\subsection{Structural Equation Models (SEM) Models}

The insight into how informants' opinion on whether Indonesia should bet decisively to position itself as a Halal tourism destination has been formed is, undoubtedly, relevant. With this aim, several models have been tested, 
taking this variable (INDON_HD) as the dependent one and using PLS technique (WarpPLS 6.0).

In the first (model 1), the four abovementioned factors have been taken as explanatory variables, producing the following output (figure 1):

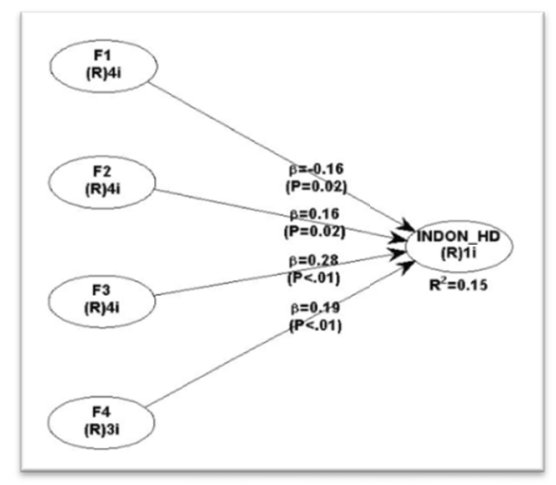

Figure 1. Model 1

The four factors have a significant effect on the variable to be explained, being F3 ("Religious profile") the most influential. Therefore, the more the respondents appreciate the religious profile of Halal tourism, the more they are in favor of positioning Indonesia as a Halal tourism destination. F1 also deserves a mention, due to the fact of being the only factor in which its path coefficient has a negative sign; as a result, the higher the perception of the impact of the geopolitical situation as a limitation of some positive effects of this type of tourism, the less people are inclined to bet decisively to position Indonesia as a Halal tourism destination. In spite of everything, the level of R2 is quite low, which indicates that other variables are still needed to explain much better the dependent variable. In an attempt to find out ways to raise the explanatory capacity of the model, we have tested the impact of the three dimensions (spiritual, ecological and healthy) of Halal tourism, leading to our model 2 (figure 2)

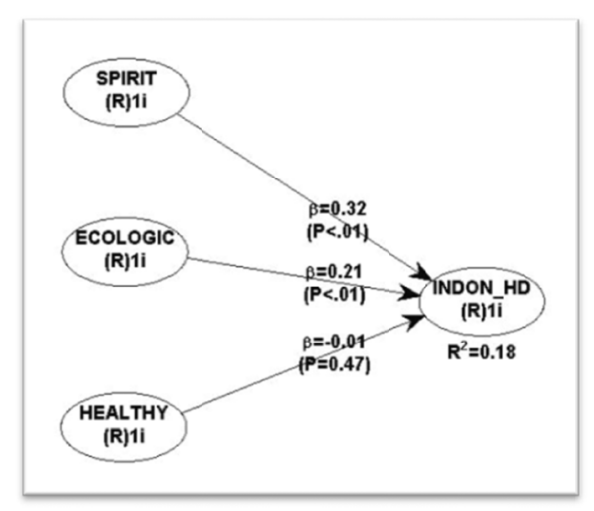

Figure 2. Model 2

Only the spiritual and ecological dimensions of Halal tourism have significant effects on the dependent variable, being the first the most influential, considering the corresponding path coefficients. Therefore, the more Halal tourism is perceived as related to the search for inner wellbeing and ecological awareness, the more favorable the opinion relative to positioning Indonesia as a Halal destination. It is worthy of note that in the relationship between Halal tourism as a second-tier (three dimensional) construct and our dependent variable, gender has been demonstrated to play a significant role as a moderating variable.

When integrating, as the next step, the four factors under which attributes describing the profile of Halal tourism have been grouped with its three dimensions, the result is displayed in our model 3 (figure 3). 


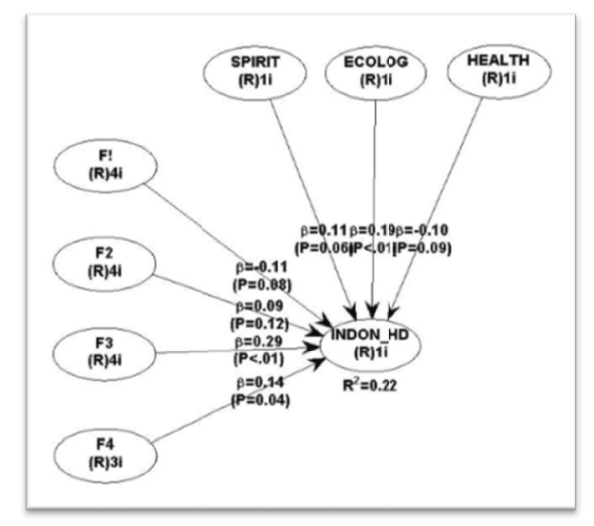

Figure 3. Model 3

As a result of the intersections among the variables in the model, R2 of the dependent variable has risen to $22 \%$, although now the effects of F1 \& F2 are no longer significant; however, F3 remains as the factor with the highest and most significant impact. From the dimensions point of view, ecological awareness becomes the most influential, while spirituality vanishes.

Model fit and quality indices of our three models are summarized in table 4. Concerning constructs' reliability and validity (all of them reflective), their Composite Reliabilities (CR) and Average Variances Extracted (AVE) follow.

CR: F1, 0.832; F2, 0.825; F3, 0.822; F4, 0.743.

AVE: F1, 0.558; F2, 0.543; F3, 0.537; F4, 0.492. All the correlations among latent variables are lower than the corresponding square root of AVE.

All this means that the requirements for reliability and validity (both convergent and discriminant) are fulfilled.

Table 4. Model fit and quality indices.

\begin{tabular}{lccc}
\hline \multicolumn{1}{c}{ Parameter } & Model 1 & Model 2 & Model 3 \\
\hline Average path coefficient (APC) & $0.195, \mathrm{P}=0.002$ & $0.177, \mathrm{P}=0.005$ & $0.146, \mathrm{P}=0.013$ \\
Average R-squared (ARS) & $0.154, \mathrm{P}=0.010$ & $0.182, \mathrm{P}=0.004$ & $0.224, \mathrm{P}<0.001$ \\
Average adjusted R-squared (AARS) & $0.133, \mathrm{P}=0.019$ & $0.167, \mathrm{P}=0.007$ & $0.190, \mathrm{P}<0.001$ \\
Average block VIF (AVIF) & 1.196 & 1.244 & 1.409 \\
Average full collinearity VIF (AFVIF) & 1.328 & 1.143 & 1.399 \\
Tenenhaus GoF (GoF) & 0.310 & 0.427 & 0.414 \\
Sympson's paradox ratio (SPR) & 0.750 & 0.667 & 0.714 \\
R-squared contribution ratio (RSCR) & 0.805 & 0.995 & 0.852 \\
Statistical suppression ratio (SSR) & 1.000 & 1.000 & 1.000 \\
Nonlinear bivariate causality direction ratio & 1.000 & 1.000 & 1.000 \\
(NLBCDR) & & & \\
\hline
\end{tabular}

Finally, as all the selected cases have a relatively high level of familiarity with Halal tourism (at least 5 over 7 in the scale used), this variable has demonstrated no explanatory capacity over our dependent variable.

\section{Conclusion and Implications}

As stated, our first aim was of a theoretical nature. Thus, the review of the related literature reflects that the study of Halal tourism is quite recent, Battour, Ismail and Battor being those who produced the first relevant article in 2010 .

A distinction is made between Islamic tourism, referred to the trip made for religious and pilgrimage purposes and, therefore, associated with acts of faith, and Halal tourism, which is made for recreational, leisure and social reasons. In this sense, the term "Halal" refers to practices allowed or approved in accordance with Islamic law (El-Gohary, 2016). 
In the literature, concepts such as Halal, Muslim or Islamic tourism are characterized by a certain degree of ambiguity, although El-Gohary (2016, p. 127, p. 130) defends that "it is preferable to use the term "Halal tourism" as the main and only term to brand and describe tourism products and/or activities that fully comply with the rules and guidance of the Halal concept and Islamic Shariah". In this sense, Halal tourism can be understood as offering tourist services designed to meet the needs of Muslim tourists in accordance with their religious obligations and practices. Thus, the Muslim tourist wants to be able to travel and to visit other places of the world maintaining their usual forms of daily life and behaviors according to Islamic law.

In this respect, it is imperative for tourism destinations to offer Halal, or at least Muslim friendly services, to attract this market segment. However, it is relevant to observe that there are no formal and unique criteria for the tourism sector. The diversity of interpretations of Islamic practices has led to different levels of demand in the world, which brings as a consequence the existence of several Halal certification organizations, which are important for attracting the Muslim market segment.

Moving to our empirical research and second aim, among the three specified dimensions of Halal tourism, its association with a healthy lifestyle is the strongest one. Second in intensity is its connection with ecological awareness and conservation of the natural environment; finally, its spiritual dimension is also vastly recognized, although with less intensity. For this new generation, therefore, attributes such as health and ecology overcome its strict religious (spiritual) dimension. This is consistent with the Indonesian Gen Z's profile drawn up by Broadbent et al (2017), when factors contributing to overall happiness were identified. In general, religion is an important pillar in their everyday lives, but a certain relaxation seems to be assumed when on vacation and travelling. Besides, if they want a clear purpose, as underlined when this generation was approached, the protection of the natural environment, together with the promotion of a healthy lifestyle, could be an argument to make them to feel more attached to the Halal movement.

It is interesting to note that the perception of their capacity to generate a high level of expenditure in the destination is relatively blurred. In addition, although their mental scheme is highly impacted by the belief of religious motivations, compatible with its potential for promoting mutual cultural understanding, only a very minor proportion of this new generation has clearly favored the religious profile of this market segment over other features of economic and social character, as revealed in the cluster analysis.

Even in a Muslim majority country such as Indonesia, only a minority of the university students ( $41 \%$ of those with Indonesian nationality) have declared themselves to be familiar enough (at least 5 on a scale of 7 points) with the Halal phenomenon, which is consistent with the low proportion who have affirmed to have been trained on this topic (only $20 \%$ of Indonesians). The level of skepticism found by Aji (2017) in Indonesia about the credibility of the Halal label could be a factor to be taken into account when analyzing this aspect.

Nevertheless, most of them believe that Indonesia should bet decisively to position itself as a Halal tourism destination, especially males. In spite of that, this position seems to vary pending on the various approaches identified relative to this phenomenon, which came up as a result of the factor and cluster analyses carried out in this study. Nevertheless, as our models have demonstrated, the religious profile is the most influential factor in favor of that position. Although much more research is needed, in order to clarify the relationship between the perception of Halal tourism and the position towards the development of this market segment, the first signs are evident here.

Increasing the level of information/knowledge on the requirements and implications of Halal tourism rises as a recommendation to educators and tourism managers in order to reach a better understanding and subsequent development of this market segment.

Halal being a relatively new concept in the research field of tourism, more attention from scholars is needed to gather new insights on this phenomenon and to approach it through different lenses, for instance, those of new generations of travelers. The awareness of the coexistence of diverse generational groups in society -Silent Generation, Baby Boomers, Generation X, Generation Y, Generation Z-, (Perdergast, 2010), is a fact with relevant practical consequences when planning tourist services and how to match them with the expectations of each of the abovementioned groups, in order to optimize tourist satisfaction and spending levels. In our understanding, this is a point of convergence of interests for both tourism professionals and academics.

Considering the findings of this study and the figures delivered in its introductory section showing the growth expectations of the Halal travel market, some implications for tourism services providers follow.

First of all, tourism operators, particularly hoteliers, are required to implement incremental changes in their services in order to succeed in this market segment, matching the needs of customers practicing Islam. 
Nonetheless, pending on the personal degree of adherence to this religion, the guest's requirements can be more or less rigorous. Hence, from the side of tourism services providers, this market specificity requires particular awareness and technical knowledge about these needs in order to be able to adequate the offer of services to the degree of adherence to religious obligations. In other words, when planning and activating innovation processes to define a number of services for intercept the needs of Halal tourism, tourism services industry must consider that the level of quality of these services have to be adapted to the diverse behaviors of each tourist. These specific tourists' needs arise from behaviors directly related to the degree of adherence to religious obligations. In other words, a careful planning and the activation of innovation processes are, in our view, essential to define a number of services capable to intercepting the Halal tourists' needs. To do so, tourism services providers must adopt a flexible approach to be able to customize the level of quality of these services to the variable profile of each tourist, directly conditioned by the interpretation and obedience of religious precepts. To this respect, the literature shows that "service quality leads to customer loyalty and attraction of new customers, positive word-of-mouth, employee satisfaction and commitment, enhanced corporate image, reduced costs, and increased business performance" (Berry et al., 1989; Akbaba, 2006).

Secondly, tourist operators must try to understand how technologies impact on the Muslim tourism segment. In other words, how technology can support the provision of services to this kind of customers with a higher level of quality, considering their religious practices and what they accordingly need -as indicated, their requirements are not necessarily homogeneous, since they can vary based on the personal interpretation of Islam and the corresponding adherence to religious duties-, and how and how much Muslim tourists use new technologies in their daily lives, with respect to their religious commitments.

So, the implications suggested in this paper can be matched with the previous theoretical background on service industries, including the tourism sector, within which the identification of excellent quality of service and high customer satisfaction are the most important challenges (Hung, Huang, \& Chen, 2003).

\section{Limitations and Future Research}

Two main limitations of this research have to be recognized: the first and most important one is the sample size, too small to be able to generalize our findings to the whole population of university students in Indonesia. The second, particularly related to the factor analysis, is the proportion of variance explained which is relatively low for this kind of technique. Nevertheless, the exploratory nature of this study allows us to present it as a first step forward in this direction, leading to further research avenues in line with overcoming these shortcomings and with the enlargement of its geographical scope. It is our conviction that this last proposal will open a fruitful field of comparative studies and the discovery of diverse cultural approaches worldwide to Halal tourism.

About future research, this study highlights the chance, and not in Muslim majority countries only, to expand the service offering to this ever more attractive market niche. Various research methodologies and tools could be used by tourism managers to better understand this segment and its opportunities. Observing the latest trends and studies in this field, a call to the integration of tourism services by cocreating value can be made. Assuming that Muslim tourists, as well as other consumers, have particular needs, tourist operators must adapt their services offer accordingly. With regard to the Halal segment, the tourism business ecosystem should be integrated not only horizontally, but also vertically, in order to address consumer needs in a comprehensive manner once considered the degree of adherence to Islamic rules (for instance through the creation of clusters of companies targeting the Halal market in tourism destinations under the basis of coordination and complementarities among them). This suggests a future research direction intended to understand better this new segment of the tourism market and how to strategically approach it, providing support to business owners and managers involved in the supply of Halal tourism services and, particularly, to hoteliers in their attempt to positioning themselves in this niche and consolidate a competitive advantage in their respective geographical scopes.

\section{Acknowledgments}

To Dr. Ajay Chauhan, Dean of the School of Business in President University (Indonesia), for facilitating the process of data gathering among his students. And to the International Institute for Research and Development of Special Interest Tourism, SITI1 (Iran).

\section{References}

Abdul Alim, E. (2017). Muslim-friendly travel: Malaysia lead over UAE narrows, Bahrain, Indonesia gain ground on leaders-study. Retrieved from https://www.salaamgateway.com/en/story/muslimfriendly_travel_malaysia_lead_over_uae_narrows_bahrai n_indonesia_gain_ground_on_leaders_study-salaam03052017145 738/ 
Aji, H. M. (2017). Does skepticism toward the Halal label exist? The empirical evidence from Indonesia. In: Advances in Islamic Business. A Book Based on Proceedings of the 8th Global Islamic Marketing Conference, 3-5 May.

Akababa, A. (2006). Measuring service quality in the hotel industry: A study in a business hotel in Turkey. International Journal of Hospitality Management, 25, 170-192. https://doi.org/10.1108/IJCHM-06-2013-0254

Bahardeen, F. (2017). Indonesia nabs third spot in Global Muslim Travel Index 2017. Retrieved from http://www.thejakartapost.com/travel/2017/05/05/indonesia-nabs-third-spot-in-global-muslim-travel-index2017.html \& http://www.tourismindonesia.com/2017/05/indonesia-nabs-third-spot-in-global.html?m=1.

Battour, M., \& Ismail, M. N. (2016). Halal tourism: Concepts, practises, challenges and future. Tourism Management Perspectives, 19(B), 150-154. https://doi.org/10.1016/j.tmp.2015.12.008

Battour, M., Ismail, M. N., \& Battor, M. (2010). Towards a Halal tourism market. Tourism Analysis, 15(4), 461-470. https://doi.org/10.1016/j.tmp.2015.12.014

Battour, M., Ismail, M. N., \& Battor, M. (2011). The impact of destination attributes on Muslim tourist's choice. International Journal of Tourism Research, 13(6), 527-540. https://doi.org/10.1002/jtr.824

Berry, L. L., Bennet, D. R., \& Brown, C. W. (1989). Service Quality: A Profit Strategy for Financial Institutions. Dow-Jones-Irwin, Homewood, IL.

Broadbent, E., Gougoulis, J., Lui, N., Pota, V., \& Simons, J. (2017). Generation Z: Global Citizenship Survey. What the World's Young People Think and Feel. London: Varkey Foundation.

Carboni, M., \& Janati, M. I. (2016). Halal tourism de facto: A case from Fez. Tourism Management Perspectives, 19(B), 155-159. https://doi.org/10.1016/j.tmp.2015.12.007

Carboni, M., Perelli, C., \& Sistu, G. (2014). Is Islamic tourism a viable option for Tunisian tourism? Insights from Djerba. Tourism Management Perspectives, 11(July), 1-9. https://doi.org/10.1016/j.tmp.2014.02.002

El-Gohary, H. (2016). Halal tourism, is it really Halal? Tourism Management Perspectives, 19(B), 124-130. https://doi.org/10.1016/j.tmp.2015.12.013.

Fink A. (1998). Conducting research literature reviews: from paper to the internet. Thousand Oaks: Sage.

Ghosh, S. (2016). Six things brands need to learn about Generation Z. Retrieved from https://www.mysalaam.com/en/story/six-things-brands-need-to-learn-about-generation-z/SALAAM171020 16061329.

Half, R. (2016). Generation Z: The up and coming workforce. Retrieved from http://www.thejakartapost.com/youth/2016/04/04/generation-z-the-up-and-coming-workforce-html

Hamza, I. M., Chouhoud, R., \& Tantawi, P. (2012). Islamic tourism: Exploring perceptions and possibilities in Egypt. African Journal of Business and Economic Research, 7(1), 85-98. Retrieved from http://hdl.handle.net/10520/EJC120526

Hays.com. (2017). Welcome Gen Z: Here's what employers want from you - and how far they'll adapt. Retrieved from https://www.hays.com.sg/press-releases/HAYS_1890617

Henderson, J. C. (2010). Sharia-compliant hotels. Tourism and Hospitality Research, 10(3), 246-254. https://doi.org/10.1057/thr.2010.3

Henderson, J. C. (2016). Halal food, certification and Halal tourism: Insights from Malaysia and Singapore. Tourism Management Perspectives, 19(B), 160-164. https://doi.org/10.1016/j.tmp.2015.12.006

Hung, Y. H., Huang, M. L., \& Chen, K. S. (2003). Service quality evaluation by service quality performance matrix. Total Quality Management and Business Excellence, 14(1), 79-89. https://doi.org/doi.org/10.1080/14783360309706

Jaelani, A. (2017). Halal tourism industry in Indonesia: potential and prospects. MPRA Paper No. 76235, Retrived from https://mpra.ub.uni-muenchen.de/76235/

Jafari, J., \& Scott, N. (2014). Muslim world and its tourisms. Annals of Tourism Research, 44(January), 1-19. https://doi.org/10.1016/j.annals.2013.08.011

Lipka, M. (2016). Muslims and Islam: Key findings in the U.S and around the world. Washington: Pew Research Center. 
Mastercard-Crescentrating (2017). Global Muslim Tourism Index 2017. Retrieved from https://newsroom.mastercard.com/asia-pacific/files/2017/05/Report-Mastercard-CrescentRating-GMTI-201 7-20mb.pdf

Mastercard-Crescentrating. (2018). Global Muslim Tourism Index 2018. Retrieved from https://www.crescentrating.com/halal-muslim-travel-market-reports.html

Mazrui, A. A. (1997). Islamic and Western values. Foreign Affairs, 76(5), 118-132.

Meredith, J. (1993). Theory building through conceptual methods. International Journal of Operations \& Production Management, 13(5), 3-11. https://doi.org/10.1108/01443579310028120

Mohsin, A., Ramli, N., \& Alkhulayfi, B. A. (2016). Halal tourism: Emerging opportunities. Tourism Management Perspectives, 19(B), 137-143. https://doi.org/10.1016/j.tmp.2015.12.010

Mukhtar, A., \& Butt, M. M. (2012). Intention to choose Halal products: The role of religiosity. Journal of Islamic Marketing, 3(2), 108-120. https://doi.org/10.1108/17590831211232519

Oktadiana, H., Pearce, P. L., \& Chon, K. (2016). Muslim travellers' needs: What don't we know? Tourism Management Perspectives, 20(October), 124-130. https://doi.org/10.1016/j.tmp.2016.08.004

Pendergast, D. (2010). Getting to know the Y Generation. In P. Benckendorff, G. Moscardo, \& D. Pendergast (Eds.), Tourism and Generation $Y$ (pp. 1-15). Wallingford, UK: CABI.

Pew Research Center, (2011). The Future of the Global Muslim Population. Demographic study. Retrieved from http://www.pewforum.org/2011/01/27/the-future-of-the-global-muslim-population/.

Pudjiarti, H. (2015). Will Generation $Z$ Change Culture in Career World? Retrieved from https://en.tempo.co/read/news/2015/07/15/240684058/Will-Generation-Z-Change-Culture-in-Career-World.

Razzaq, S., Hall, C. M., \& Prayag, G. (2016). The capacity of New Zealand to accommodate the halal tourism market-Or not. Tourism Management Perspectives, 18(April), 92-97. https://doi.org/doi.org/10.1016/j.tmp.2016.01.008

Samori, Z., Salleh, N. Z. M., \& Khalid, M. M. (2016). Current trends on Halal tourism: Cases on selected Asian countries. Tourism Management Perspectives, 19(B), 131-136. https://doi.org/10.1016/j.tmp.2015.12.011

Sandikci, Ö. (2011). Researching Islamic marketing: Past and future perspectives. Journal of Islamic Marketing, 2(3), 246-258. https://doi.org/10.1108/17590831111164778

Scott, N., \& Jafari, J. (2010). Islam and tourism. In N. Scott, \& J. Jafari (Eds.), Tourism in the Muslim world, (pp. 1-13). Bingley: Emerald Group Publishing Limited.

Selvarajah, K., Che Musa, C. O., Irsyad, Z., Nazreen, S., \& Sharifah, A. (2017). The Awareness of Gen Z's toward Halal Food Industry. Management, 7(1), 44-47.

Shakona, M., Backman, K., Backman, S., Norman, W., Luo, Y., \& Duffy, L. (2015). Understanding the traveling behavior of Muslims in the United States. International Journal of Culture, Tourism and Hospitality Research, 9(1), 22-35. https://doi.org/10.1108/IJCTHR-05-2014-0036

Singh, S. (2013). Generation Z: Rules to Reach the Multinational Consumer. Boston: Sapient.

Stephenson, M. L. (2014). Deciphering 'Islamic hospitality': Developments, challenges and opportunities. Tourism Management, 40, 155-164. https://doi.org/10.1016/j.tourman.2013.05.002

UNWTO \& WYSE Travel Confederation (2016). Global Report on The Power of Youth Travel, UNWTO, ISBN electronic version 978-92-844-1716-2. $\quad$ Retrieved from http://cf.cdn.unwto.org/sites/all/files/pdf/wyse_powerofyouthtravel.pdf

UNWTO \& WYSE Travel Confederation. (2016). The power of youth travel. Madrid: UNWTO.

Verghese, V. (2017). Halal travel gets green light. Retrieved from http://www.smarttravelasia.com/archive/1706/check-in.htm

WTM. (2007). The world travel market global trends reports 2007. London: World Travel Market.

Zamani-Farahani, H., \& Henderson, J.C. (2010). Islamic tourism and managing tourism development in Islamic societies: The cases of Iran and Saudi Arabia. International Journal of Tourism Research, 12(1), 79-89. https://doi.org/10.1002/jtr.741

Zamani-Farahani, H., \& Musa, G. (2012). The relationship between Islamic religiosity and residents' perceptions of socio-cultural impacts of tourism in Iran: Case studies of Sarre'in and Masooleh. Tourism Management, 


\section{3(4), 802-814. https://doi.org/10.1016/j.tourman.2011.09.003}

\section{Notes}

Note 1. 24 results are released by WoS when searching this topic. Battour and Ismail are the most prolific au-thors, followed by Henderson and El-Gohary. Tanta University, in Egypt, and the University of Malaya, in Malaysia, are the institutions where most of the documents have been produced. The breakdown of their years of publication follows chronologically: 2010: $2 ; 2011: 1 ; 2012: 2 ; 2013: 2 ; 2014: 3 ; 2015: 5 ; 2016: 8$. At the date of the search, 1 extra document should be counted, corresponding to 2017, high-lighting how recent this field of study is, with the first documents dating back to 2010. Nevertheless, this figure rises to 44 in Scopus, with three previous documents published in 2004, 2006 and 2009. Nanyang Technological University (Singapore) and International Islamic University Malaysia have to be added to the previous list of outstanding institutions because of their production in this field. Most of the documents $(84 \%)$ are classified within the area of business and management.

Note 2. More specifically, this is the proportion who Agree or Strongly Agree with all of the following statements: 'Religious faith is important in my life'; 'Religious faith is important to my parents'; 'My parents' religion will play an important role in my decision to marry; 'A person's religion is an important factor to me when deciding whether to be friends with someone.

\section{Copyrights}

Copyright for this article is retained by the author(s), with first publication rights granted to the journal.

This is an open-access article distributed under the terms and conditions of the Creative Commons Attribution license (http://creativecommons.org/licenses/by/4.0/). 